\title{
INCIDENCE OF PATHOGENIC ESCHESICHIA COLI IN SOME POULTRY SPECIES IN EGYPT AND ITS EFFECT ON CHICKENS PERFORMANCE
}

\begin{abstract}
A.M. Hegazy, A. Ismail', H.A. ABDALLAH', W.F. S. Ibrahim ${ }^{2}$
'Avian and Rabbit Medicine Department, Faculty of Veterinary Medicine, Zagazig University, Zagazig 44519, Egypt. ${ }^{2}$ Educational 2Veterinary Hospital, Faculty of Veterinary Medicine, Zagazig University, Zagazig 44519, Egypt. ${ }^{3}$ Food Control Department, Faculty of Veterinary Medicine, Zagazig University, Zagazig 44519, Egypt.

ABSTRACT

The highest incidence of positive pathogenic E.COLI (APEC) isolated in this study was from chickens (57.96\%) followed by ducks ,pigon, turkey, ibis and quail with a percentage ,25.48\%, 5.10\%, 4.46\%, $3.82 \%$ and $3.18 \%$ respectively. Heart, liver and lungs were the important tissues in production of APEC E.COLI O26 , O127, O55, O119, O111, O78, O86, O2 and O114 were the most prevalent serogroups identified in this study using PCR five virulance associated genes in the APEC serogroups were irp2, iron, ompt, iss and hlyf from all examined isolates . xperimental infection of broiler chickens with the different isolated E.coli serogroups, 078 and o2 showed the highest mortality rates $60 \%$ and $50 \%$ respectively with severe reduction in the mean body weight from 20-30\%. Antibiotic sensitivity of the isolated APEC was studied.
\end{abstract}

\section{INTRODUCTION}

The association of Escherichia coli strains with disease conditions in avian species was recognized over a century ago, but these strains were never accorded a special status (Qadri et al., 1994). However, lesions in which $E$. coli is the primary and often the secondary agent 
cause economic damage due to lower corporal development, insufficient feed conversion, increasing mortality, higher cost with medicine, and condemnation of carcasses (Brasil, 2006).

E. coli strains causing systemic disease in poultry (avian colibacillosis) are termed avian pathogenic $E$. coli (APEC). Colibacillosis is a disease of severe economic significance to all poultry producers worldwide and is characterized by a diverse array of lesions. The most common lesions associated with colibacillosis are perihepatitis, airsacculitis and pericarditis, although other syndromes such as egg peritonitis, salpingitis, coligranuloma, omphlitis, cellulitis and osteomyelitis, arthritis may be encountered (Gomis et al., 2001).

APEC strains fall under the category of extraintestinal pathogenic E. coli, which are characterized by the possession of virulence factors that enable to live extraintestinal life. These virulent factors have been identified (Dozois et al., 2000; Johnson et al., 2006). However, no specific virulent factor that contributes entirely to the pathogenicity of APEC has been discovered (Province and Curtis, 1994). Multiplex PCR was proved that virulent strains which are already typed as APEC had 5 to 8 virulence-associated genes but avirulent strains which are already typed as non-APEC strains had at most 4 virulence-associated genes (Ewers et al., 2005).

Thus the aim of this study was to detect APEC from some poultry species (chickens, ducks, turkeys, pigeons, quail and ibis )using different diagnostic tools including polymerase chain reaction (PCR). In addition, the sensitivity of the confirmed APEC strains to various antibiotics used in Egypt, as well as the pathogenicity of some isolated serotypes for chickens were discussed. 


\section{MATERIAL AND METHODS}

\section{Sampling:}

One hundred broiler chickens, 50 ducks, 10 from each of turkey, pigeon, quail, and ibis (moribund and freshly dead) were collected from different poultry farms in Sharkia governorate, Egypt. The signs were mainly respiratory signs (coughing. sneezing, mucoid nasal secretion and gasping) and swollen head accompanied with enteritis and emaciation. Nine hundred and fifty samples from liver, lungs, air sacs, intestine and heart blood were collected for bacteriological examination (500 sample from chickens, 250 sample from ducks and 50 sample from each of the examined other poultry species).

\section{Bacteriological examination:}

Tissue samples were platted on MacConkey agar plates (Difco, Detroit, MI, USA). The lactose fermenting colonies were reinoculated to Eosin Methyline Blue agar plates (Difco, Detroit, MI, USA). Metallic sheen colonies were transferred to Nutrient agar slants and incubated at $37^{\circ} \mathrm{C}$ for $24 \mathrm{~h}$ and then stored at $4^{\circ} \mathrm{C}$ for further identification. Identification of isolates was done according to Cloud et al., (1985).

\section{Serodiagnosis of E.coli:}

The confirmed E. coli isolates were serologically identified according to Kok et al., (1996) by using rapid diagnostic E.coli antisera sets (Difco, Detroit, MI, USA) for diagnosis of the Enteropathogenic types. 
DNA preparation and Detection of virulence factors by Polymerase Chain Reaction (PCR):

Each of glycerol stock serodiagnosed E. coli was incubated in Nutrient broth (Difco) and grown overnight in shaking incubator at $37^{\circ}$ C. The enriched medium in a 1.5 ml-eppindorf tube was microcentrifuged in $1,500 \mathrm{rpm}$ for $10 \mathrm{~min}$, and the supernatant was discarded. Autoclaved distilled water (DW) or TE buffer (10 mM Tris$\mathrm{HCl}, 1 \mathrm{mM}$ EDTA at $\mathrm{pH} 8.0$ ) was added to the pellet, Then freezed for $10 \mathrm{~min}$ at $-80^{\circ} \mathrm{C}$, and incubated (boiled) for $5 \mathrm{~min}$ at $95^{\circ} \mathrm{C}$. After repeating this procedure 3 to 4 times, and then centrifuged again in 1,500 rpm for 10 min. DNA concentration in supernatant was evaluated by Nanodrop (ND-1000, Nanodrop Technologies, Wilmington, DE, USA).

Tested E. coli were examined for astA, irp2, iroN, ompT, iss, hlyF, IutA and $t s h$ virulent genes using PCR. The PCR procedure was applied after DNA extraction, according to the protocol described by Boom et al., (1990).

\section{Antibiogram:}

Antibiotic sensitivity test was performed according to the procedures of Aerts et al. (1995).

\section{Experimental infection:}

One hundred, two weeks old Ross chicks were divided into 10 groups table (1) 
Incidence Of Pathogenic Eschesichia Coli In Some Poultry ...

Table (1): Experimental design for Experimental infection)

\begin{tabular}{|c|c|c|c|c|c|c|}
\hline Groups & Number & $\begin{array}{c}\text { Serotypes } \\
\text { coli }\end{array}$ & Dose & Route & Treatment & Re isolation \\
\hline$\overline{1}$ & 10 & O26 & \multirow{9}{*}{$\begin{array}{c}1 * 108 \\
\text { Cfu Former et al., } \\
1994\end{array}$} & \multirow{9}{*}{$\mathbf{I} / \mathbf{M}$} & \multirow{9}{*}{$\begin{array}{c}\text { Norfloxacin } \\
10 \mathrm{mg} / \mathrm{kg} \text { for } 3-5 \\
\text { days after onset } \\
\text { of symptoms }\end{array}$} & \multirow{9}{*}{$\begin{array}{c}\text { From faeces at } \\
28,35 \text { and } 42 \\
\text { days old }\end{array}$} \\
\hline 2 & 10 & $\mathbf{O 2 7}$ & & & & \\
\hline 3 & 10 & 0111 & & & & \\
\hline 4 & 10 & 0119 & & & & \\
\hline 5 & 10 & 086 & & & & \\
\hline 6 & 10 & 02 & & & & \\
\hline 7 & 10 & O78 & & & & \\
\hline 8 & 10 & 0114 & & & & \\
\hline 9 & 10 & 055 & & & & \\
\hline 10 control & 10 & - & - & - & - & - \\
\hline
\end{tabular}

Infection in all groups at 21 day of age, BW, FL and FCR were estimated at 28,35 and 42 days old.

\section{RESULTS}

Heart blood was reported to have the highest incidence of the biochemically identified $E$. coli isolates in all species examined in our study. Lungs came second to heart followed by liver, spleen and air sacs. The total percentage of $E$. coli isolates in these tissues in all species examined were $31.85 \% ; 22.93 \% ; 18.47 \% ; 14.01 \%$ and $12.74 \%$ respectively (Table2).

The highest incidence of positive $E$. coli isolates was recorded to be in chicken (57.96\%), followed by ducks (25.48\%), pigeon $(5.10 \%)$, turkey $(4.46 \%)$, ibis $(3.82 \%)$ and quail $(3.18 \%)$ as shown in Table2. This result is considered reasonable and parallel with the high numbers of chicken farms in Egypt compared with other poultry species.

Interestingly, Ibis which is usually observed flying around poultry farms in Egypt all over the year, found to harbor avian pathogenic E. coli (Table2). 
Table (2): Incidence of positive E.COLI isolates and serogroups from tissues of diffirent avian species

\begin{tabular}{|c|c|c|c|c|c|c|c|c|c|c|c|c|c|c|c|c|c|c|}
\hline \multirow[b]{2}{*}{ 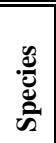 } & \multicolumn{6}{|c|}{$\overline{~+\text { +ve E.COLI samples biochemically }}$} & \multicolumn{12}{|c|}{ +veE.COLI } \\
\hline & 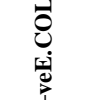 & $\stackrel{\mathscr{D}}{\Xi}$ & 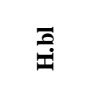 & 吾 & ? & $\overline{\mathrm{n}}$ & రี & $\hat{a}$ & $\bar{\Xi}$ & हे & 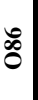 & ชี & $\stackrel{\infty}{5}$ & $\frac{\pi}{0}$ & : & $\overline{0}$ & $\bar{z}$ & $\stackrel{\overbrace{}}{0}$ \\
\hline $\mathrm{ch}$ & $57.96 \%$ & $19(20 \%)$ & $31.9 \%$ & $25.3 \%$ & $13.2 \%$ & $8.8 \%$ & 17 & 18 & 0 & 16 & 0 & 0 & 12 & 0 & 26 & 89 & 2 & 91 \\
\hline $\mathrm{D}$ & $25.48 \%$ & $6(15 \%)$ & $25.5 \%$ & $20 \%$ & $15 \%$ & $22.5 \%$ & 7 & 8 & 13 & 0 & 11 & 0 & 0 & 0 & 0 & 39 & 1 & 40 \\
\hline $\mathrm{T}$ & $4.46 \%$ & \begin{tabular}{|c}
$1(14.3$ \\
$\%)$
\end{tabular} & $42.9 \%$ & $28.6 \%$ & $0 \%$ & $14.3 \%$ & 2 & 1 & 0 & 0 & 0 & 2 & 0 & 0 & 0 & 5 & 2 & 7 \\
\hline $\mathrm{p}$ & $5.10 \%$ & $\mid 2(25 \%)$ & $37.5 \%$ & $12.5 \%$ & $12.5 \%$ & $12.5 \%$ & 4 & 3 & 0 & 0 & 0 & 0 & 0 & 0 & 0 & 7 & 1 & 8 \\
\hline $\mathrm{ib}$ & $3.82 \%$ & $0(0 \%)$ & $33.3 \%$ & $16.7 \%$ & $16.7 \%$ & $33.3 \%$ & 2 & 1 & 0 & 0 & 0 & 0 & 0 & 2 & 0 & 5 & 1 & 6 \\
\hline Q & $3.18 \%$ & $1(20 \%)$ & $40 \%$ & $20 \%$ & $0 \%$ & $20 \%$ & 1 & 2 & 0 & 0 & 0 & 0 & 0 & 0 & 0 & 3 & 2 & 5 \\
\hline Total & $\begin{array}{c}157 \\
(100 \%)\end{array}$ & \begin{tabular}{|c}
29 \\
$(18.47 \%)$
\end{tabular} & $\begin{array}{c}50 \\
(31.85 \%)\end{array}$ & \begin{tabular}{|c}
36 \\
$(22.93 \%$
\end{tabular} & $\begin{array}{c}20 \\
(12.74 \%\end{array}$ & $\begin{array}{c}22 \\
(14.01 \%)\end{array}$ & & & & & & & & & & & & \\
\hline
\end{tabular}

Total $^{2}$ refers to total number of both identified and untyped E. coli serogroups

TO1=TOTAL1

TO2=TOTAL2

$\mathrm{UNT}=\mathrm{UNTYPED}$

$$
\begin{aligned}
& \text { H.bl=heart blood } \\
& \text { A.S=air sacs }
\end{aligned}
$$

Spl=spleen

The majority of APEC strains (94.3\%) were typeable with standard $\mathrm{O}$ antisera; from the typeable isolates (148), a total of 9 different $\mathrm{O}$ serogroups were identified (Table2). The most prevalent serogroups in different examined poultry species were O26 (21\%), O127 (19.7\%), O55 (16.6\%), O119 (11.5\%), O111 (8.3\%), O78 (7.6\%), O86 (7\%), finally both of $\mathrm{O} 2$ and $\mathrm{O} 114(1.3 \%)$.

Our PCR results confirmed that all identified E. coli serotypes were classified to belong to APEC, Patterns and combinations of virulenceassociated genes for 9 APEC strains isolated in the present study are summarized in Fig. 1 and Table3. Although the specimen origins of APEC strains were diverse, the existence of virulence-associated genes had similar patterns (Table3, Fig. 1). 
Incidence Of Pathogenic Eschesichia Coli In Some Poultry ...

Table (3): Distribution of virulent genes in the serogroups of $E$. coli isolates used in the PCR analysis

\begin{tabular}{|c|c|c|c|c|c|c|c|c|c|}
\hline Virulent genes & O86 & O127 & $\mathrm{O} 114$ & $\mathrm{O} 26$ & $\mathrm{O} 78$ & O119 & O111 & O55 & $\mathrm{O} 2$ \\
\hline astA & + & + & + & - & + & + & - & + & + \\
\hline $\operatorname{Irp2}$ & + & + & + & + & + & + & + & + & + \\
\hline Iron & + & + & + & + & + & + & + & + & + \\
\hline ompT & + & + & + & + & + & + & + & + & + \\
\hline Iss & + & + & + & + & + & + & + & + & + \\
\hline hly $F$ & + & + & + & + & + & + & + & + & + \\
\hline IutA & + & \pm & \pm & + & + & - & - & - & + \\
\hline Tsh & + & \pm & \pm & + & + & + & - & - & + \\
\hline
\end{tabular}

On average, detection rate of Irp2, iron, ompT, iss and hly genes showed that they existed in APEC strains with 100\% (Table3, Fig. 1).

Our data showed that the identified serogroups from different poultry species showed a marked sensitivity to newly used antibiotics in Egypt like cefotaxin and Norfloxacin and variable degrees of sensitivity to other antibiotics as shown in table 4.

Table (4): Antibiogram of various pathogenic E. coli serogroups isolated from examined poultry species towards various antibiotics

\begin{tabular}{|c|c|c|c|c|c|c|c|c|c|c|}
\hline Antibiotic & & 026 & 0127 & 0111 & 0119 & 086 & $\mathbf{O 2}$ & O78 & 0114 & 055 \\
\hline Cefotaxin (CTX) & $30 \mathrm{mg}$ & +++ & ++++ & +++ & ++++ & ++++ & +++ & ++ & +++ & +++ \\
\hline Norfloxacin (NOR) & $10 \mathrm{mg}$ & +++ & ++ & ++ & +++ & ++ & ++ & +++ & ++++ & + \\
\hline Ciprofloxacin (CIP) & $5 \mathrm{ug}$ & + & + & +++ & +++ & +++ & ++++ & +++ & +++ & + \\
\hline Danofloxacin (DAN) & $5 \mathrm{mg}$ & ++++ & + & ++ & +++ & ++ & ++++ & ++ & ++++ & + \\
\hline Streptomycin (S) & $10 \mathrm{mg}$ & ++ & + & + & ++ & ++ & +++ & + & + & ++ \\
\hline Azithromycin (AT) & $15 \mathrm{mg}$ & - & +++ & + & +++ & ++ & ++ & +++ & ++ & ++ \\
\hline Amoxicilline (AX) & $25 \mathrm{mg}$ & ++++ & - & ++++ & + & +++ & +++ & + & ++ & + \\
\hline Florfenicol (FFC) & $30 \mathrm{mg}$ & ++++ & + & + & - & + & +++ & ++ & +++ & ++++ \\
\hline
\end{tabular}

$(++++)$ Highly sensitive, (+++) Moderately sensitive, (++) Sensitive, (+) Weakly sensitive, (-) Nonsensitive.

$\overline{\text { Kafrelsheikh Vet. Med. J. Vol. } 15 \text { No. } 1 \text { (2017) }}$ 
Ross chickens were experimentally infected with the different isolated E.coli serotypes. The mortality rates of this experimental infection were clarified in (Table5). It was shown that E.coli O 78 and O2 had the highest mortality rates with percentages of $60 \%$ and $50 \%$ respectively, while E.coli $\mathrm{O} 111$ and $\mathrm{O} 55$ had the least mortality rates in Ross chickens with percentages of $10 \%$ for each. Other E.coli serogroups had variable effects on the experimentally infected chickens as E.coli mortality pattern was 40, 30 and $60 \%$ due to infection with O86, O119 and $\mathrm{O} 26$ respectively. Both of $\mathrm{O} 127$ and $\mathrm{O} 114$ led to $20 \%$ mortality among their infected groups (Table5). These results were considered reasonable as they were parallel with the harboring of the virulence associated genes, as E.coli O2, O78 and O86 had 100\% of the examined virulent factors, While E.coli O55 and $\mathrm{O} 111$ had only 6 and 5 out of 8 tested virulence associated genes (Figure 1 and Table3

Experimental infection with different E.coli serotypes in Ross chicken led to a significant decrease in mean body weight for all infected groups (1-9) groups, at $4^{\text {th }}$ week (before treatment).

E.coli O2 had the lowest mean body weight 705.221 \pm 29.547 compared with the control 1090.55 \pm 10.883 . Other E.coli serotypes led to severe reduction in the mean body weight about $20-30 \%$ reduction (Table5). This reduction was continuous till $6^{\text {th }}$ week of the experiment compared with the control, although much improved after treatment (Table5). Our results correspond with the findings of Hui et al., (2002) and Oh et al., (2011). 
Incidence Of Pathogenic Eschesichia Coli In Some Poultry ...

Table (5): Effect of E coli infection on mean body weight, feed intake and feed conversion ratio ,3,4 and 5 weeks post infection

\begin{tabular}{|c|c|c|c|c|c|c|c|c|c|c|c|}
\hline \multicolumn{2}{|c|}{ Group } & $\overline{1 \text { 1st }}$ & 2nd & $3^{\text {rd }}$ & $\overline{4 \text { 4th }}$ & $\overline{5 \text { 5th }}$ & $\overline{\text { 6th }}$ & $\overline{7 \text { 7th }}$ & $\overline{8 \text { 8th }}$ & 9th & p10th \\
\hline \multicolumn{2}{|c|}{$\begin{array}{c}\text { E.coli } \\
\text { serology }\end{array}$} & $\mathrm{O} 26$ & $\mathrm{O} 127$ & O111 & O119 & O86 & $\mathrm{O} 2$ & $\mathrm{O} 78$ & O114 & O55 & Control \\
\hline \multicolumn{2}{|c|}{ No. of birds } & 10 & 10 & 10 & 10 & 10 & 10 & 10 & 10 & 10 & 10 \\
\hline \multicolumn{2}{|c|}{ Mortality \% } & 30 & 20 & 10 & 30 & 40 & 50 & 60 & 20 & 10 & 0 \\
\hline \multicolumn{2}{|c|}{ Re isolation } & $+\mathrm{ve}$ & $+\mathrm{ve}$ & $+\mathrm{ve}$ & $+\mathrm{ve}$ & $+\mathrm{ve}$ & $+\mathrm{ve}$ & $+\mathrm{ve}$ & $+\mathrm{ve}$ & $+\mathrm{ve}$ & -ve \\
\hline \multirow{3}{*}{ 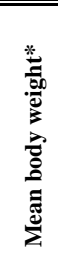 } & $\begin{array}{c}28 \\
\text { day }\end{array}$ & \begin{tabular}{|c}
$813.25 \mathrm{bc}$ \\
\pm 31.473
\end{tabular} & $\begin{array}{c}814.626 \mathrm{~b} \\
\pm 32.423\end{array}$ & $\begin{array}{c}814.26 \text { bc } \\
\pm 36.211\end{array}$ & $\begin{array}{l}829.87 \mathrm{~b} \\
\pm 27.008\end{array}$ & $\mid \begin{array}{c}825.48 \mathrm{~b} \\
\pm 13.53\end{array}$ & $\begin{array}{c}705.221 \mathrm{c} \\
\pm 29.547\end{array}$ & $\begin{array}{c}737.33 \mathrm{bc} \\
\pm 28.715\end{array}$ & $\begin{array}{c}744.825 \\
\text { bc } \\
\pm 26.496\end{array}$ & $\begin{array}{c}890.45 \mathrm{~b} \\
\pm 12.883\end{array}$ & $\begin{array}{c}1090.55 \mathrm{a} \\
\pm 10.883\end{array}$ \\
\hline & $\begin{array}{l}35 \\
\text { day }\end{array}$ & $\begin{array}{l}1033.25 \mathrm{c} \\
\pm 19.811\end{array}$ & $\begin{array}{l}1096.6 \mathrm{c} \\
\pm 21.753\end{array}$ & $\begin{array}{r}1058.1 \mathrm{c} \\
\pm 25.578\end{array}$ & $\begin{array}{c}1136.625 b \\
\pm 30.82\end{array}$ & $\begin{array}{c}1119.9 \mathrm{~b} \pm 1 \\
1.003\end{array}$ & $\begin{array}{l}1003.3 \mathrm{c} \\
\pm 17.05\end{array}$ & $\begin{array}{l}1018.0 \mathrm{c} \\
\pm 37.29\end{array}$ & $\begin{array}{c}1051.57 \mathrm{c} \pm \\
2.707\end{array}$ & $\begin{array}{c}1315.7 b \pm 2 \\
2.4535\end{array}$ & $\begin{array}{c}1515.7 \mathrm{a} \\
\pm 12.4535\end{array}$ \\
\hline & $\begin{array}{c}42 \\
\text { day }\end{array}$ & $\begin{array}{c}1307.35 \mathrm{c} \\
\pm 18.088\end{array}$ & $\begin{array}{c}1386.967 \mathrm{c} \\
\pm 19.885\end{array}$ & $\begin{array}{r}1372.1 \mathrm{c} \\
\pm 21.952\end{array}$ & $\begin{array}{c}1550.625 b \\
\pm 26.403\end{array}$ & $\begin{array}{c}1507.14 \mathrm{~b} \pm \\
12.365\end{array}$ & $\begin{array}{r}1319.14 \mathrm{c} \\
\pm 16.862\end{array}$ & $\begin{array}{c}1370.2 \mathrm{c} \pm 2 \\
7.32\end{array}$ & $\begin{array}{c}1547.45 b \pm \\
24.703\end{array}$ & $\begin{array}{c}1608.4 b \pm 1 \\
2.371\end{array}$ & $\begin{array}{l}1908.4 \mathrm{a} \\
\pm 12.371\end{array}$ \\
\hline \multirow{3}{*}{ 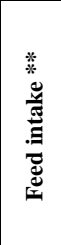 } & $\begin{array}{c}28 \\
\text { day }\end{array}$ & $\begin{array}{c}640.0 \mathrm{~b} \\
\pm 9.0711\end{array}$ & \begin{tabular}{|c|}
$659.0 \mathrm{~b}$ \\
\pm 42.7735
\end{tabular} & $\begin{array}{c}638.0 \mathrm{~b} \\
\pm 15.7735\end{array}$ & $\begin{array}{c}655.0 \mathrm{~b} \\
\pm 7.9511\end{array}$ & $\begin{array}{c}648.0 \mathrm{~b} \pm 17 \\
.0711\end{array}$ & $\begin{array}{c}602.0 \mathrm{c} \\
\pm 18.160\end{array}$ & \begin{tabular}{|c|}
$600.0 \mathrm{c}$ \\
\pm 15.7735
\end{tabular} & $\begin{array}{c}650.0 \mathrm{~b} \pm 5 \\
7735\end{array}$ & \begin{tabular}{|c|}
$650.0 \mathrm{~b}$ \\
\pm 17.0711
\end{tabular} & $\begin{array}{c}750.0 \mathrm{a} \\
\pm 15.6195\end{array}$ \\
\hline & $\begin{array}{l}35 \\
\text { day }\end{array}$ & $\begin{array}{c}748.0 \mathrm{~b} \\
\pm 17.0711\end{array}$ & \begin{tabular}{|}
$738.03 b$ \\
\pm 10.5774
\end{tabular} & $\begin{array}{c}728.03 b \\
\pm 10.5774\end{array}$ & $\begin{array}{c}740.0 \mathrm{~b} \\
\pm 24.0825\end{array}$ & $\begin{array}{c}687.5 c \pm 10 \\
.4082\end{array}$ & $\begin{array}{c}680.0 \mathrm{c} \\
\pm 28.1650\end{array}$ & $\begin{array}{c}752.0 \mathrm{~b} \\
\pm 15.7735\end{array}$ & $\begin{array}{c}748.3 b \pm 10 \\
.5774\end{array}$ & \begin{tabular}{|c}
$740.0 \mathrm{~b}$ \\
\pm 17.0711
\end{tabular} & $\begin{array}{c}853.0 \mathrm{a} \\
\pm 15.6195\end{array}$ \\
\hline & $\begin{array}{c}42 \\
\text { day }\end{array}$ & \begin{tabular}{|c}
$859.0 \mathrm{~b}$ \\
\pm 17.0711
\end{tabular} & $\begin{array}{c}847.0 \mathrm{~b} \\
\pm 20.8167\end{array}$ & $\begin{array}{c}860.0 \mathrm{~b} \\
\pm 20.8163\end{array}$ & $\begin{array}{c}850.0 \mathrm{~b} \\
\pm 24.0825\end{array}$ & $\begin{array}{c}840.0 \mathrm{~b} \pm 26 \\
.3299\end{array}$ & $\begin{array}{c}817.0 \mathrm{c} \\
\pm 18.1650\end{array}$ & $\begin{array}{c}805.0 \mathrm{c} \\
\pm 25.7735\end{array}$ & $\begin{array}{c}847.0 \mathrm{~b} \pm 20 \\
.8160\end{array}$ & \begin{tabular}{|c|}
$850.0 \mathrm{~b}$ \\
\pm 27.0711
\end{tabular} & $\begin{array}{c}880.0 \mathrm{a} \\
\pm 15.6195\end{array}$ \\
\hline \multirow{3}{*}{ 蔯 } & $\begin{array}{c}28 \\
\text { day }\end{array}$ & \begin{tabular}{|c|c|}
$2.92 \mathrm{~b}$ \\
\pm 0.20707
\end{tabular} & $\begin{array}{c}2.81 \mathrm{~b} \\
\pm 0.1577\end{array}$ & $\begin{array}{c}2.98 \mathrm{~b} \\
\pm 0.205774\end{array}$ & \begin{tabular}{|c|}
$2.98 \mathrm{~b}$ \\
\pm 0.13707
\end{tabular} & \begin{tabular}{|c|c}
$3.38 \mathrm{c}$ \\
\pm 0.10707
\end{tabular} & $\begin{array}{c}4.35 \mathrm{~d} \\
\pm 0.2488\end{array}$ & \begin{tabular}{|c|}
$3.55 \mathrm{c}$ \\
\pm 0.10577
\end{tabular} & $\begin{array}{c}2.90 \mathrm{~b} \pm 0.2 \\
0577\end{array}$ & \begin{tabular}{|c|}
$2.83 \mathrm{~b}$ \\
\pm 0.10707
\end{tabular} & \begin{tabular}{|c|}
$1.82 \mathrm{a}$ \\
\pm 0.20743
\end{tabular} \\
\hline & $\begin{array}{c}35 \\
\text { day }\end{array}$ & \begin{tabular}{||c|}
$2.35 \mathrm{a}, \mathrm{b}$ \\
\pm 0.00707
\end{tabular} & \begin{tabular}{|c|}
$2.51 \mathrm{~b}$ \\
\pm 0.20577
\end{tabular} & \begin{tabular}{|c|}
$2.56 \mathrm{~b}$ \\
\pm 0.10577
\end{tabular} & \begin{tabular}{|c|}
$2.44 \mathrm{~b}$ \\
\pm 0.20408
\end{tabular} & \begin{tabular}{|c|c}
$2.55 \mathrm{~b}$ \\
\pm 0.10408
\end{tabular} & \begin{tabular}{|c|}
$2.81 \mathrm{c}$ \\
\pm 0.00816
\end{tabular} & \begin{tabular}{|c|}
$2.79 c$ \\
\pm 0.00577
\end{tabular} & $\begin{array}{c}2.82 \mathrm{c} \pm 0.0 \\
0577\end{array}$ & \begin{tabular}{|c|c}
$2.54 \mathrm{~b}$ \\
\pm 0.120707
\end{tabular} & \begin{tabular}{|c|}
$2.189 a$ \\
\pm 0.206588
\end{tabular} \\
\hline & $\begin{array}{c}42 \\
\text { day }\end{array}$ & \begin{tabular}{|c|c|}
$2.37 a$ \\
\pm 0.00707
\end{tabular} & \begin{tabular}{|c|}
$2.49 a$ \\
\pm 0.00577
\end{tabular} & $\begin{array}{c}2.40 \mathrm{a} \\
\pm 0.00577\end{array}$ & \begin{tabular}{|c|}
$2.29 \mathrm{a}$ \\
\pm 0.00408
\end{tabular} & \begin{tabular}{|c|}
$2.39 a$ \\
\pm 0.00408
\end{tabular} & \begin{tabular}{|c|}
$2.29 a$ \\
\pm 0.00816
\end{tabular} & \begin{tabular}{|c|}
$2.27 \mathrm{a}$ \\
\pm 0.00577
\end{tabular} & $\begin{array}{c}2.19 \mathrm{a} \pm 0.0 \\
060\end{array}$ & \begin{tabular}{||c|}
$2.29 \mathrm{a}$ \\
\pm 0.00707
\end{tabular} & $\begin{array}{c}2.47 \mathrm{a} \\
\pm 0.151088\end{array}$ \\
\hline
\end{tabular}

*=mean body weight (gram) post 3,4 and 5weeks

$=$ feed intake $($ gram $) * *$

$* * *=$ feed conversion ratio (FCR)post 3,4 and 5 weeks

Sign. $(\mathrm{P}<0.05)$

\section{DISCUSSION}

The highest incidence of positive $E$. coli isolates was recorded to be in chicken (57.96\%), followed by ducks (25.48\%), pigeon (5.10\%), turkey $(4.46 \%)$, ibis $(3.82 \%)$ and quail $(3.18 \%)$. This result is considered reasonable and parallel with the high numbers of chicken farms in Egypt compared with other poultry species.

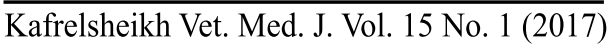


This result goes in correspondence with $X \boldsymbol{i}$ et al., (2007), who recorded 6 cases of septicemia in crested ibis (Nipponia nippon), in China, E. coli was also reported to be the cause of sudden death and severe diarrhea in these cases.

The distribution of $E$. coli in different tissues of poultry species corresponds with Youssif et al., (2008) who reported that the highest incidence of $E$. coli isolates was observed in the heart followed by liver and finally air sacs in broiler and laying chickens distributed in Ismailia province, Egypt. Internationally, similar pattern of tissue distribution of E. coli was observed in Japanese quails (Coturnix coturnix japonica) experimentally infected with the Escherichia coli serogroups O2 isolated from a turkey (Nain and Smits, 2011).

The majority of APEC strains (94.3\%) were typeable with standard $\mathrm{O}$ antisera; from the typeable isolates (148), a total of 9 different $\mathrm{O}$ serogroups were identified. The most prevalent serogroups in different examined poultry species were O26 (21\%), O127 (19.7\%), O55 (16.6\%), $\mathrm{O} 119$ (11.5\%), O111 (8.3\%), O78 (7.6\%), O86 (7\%), finally both of O2 and $\mathrm{O} 114(1.3 \%)$. These results go in agreement with Wang et al., (2010) who reported that E. coli $\mathrm{O} 26, \mathrm{O} 78$ and $\mathrm{O} 2$ were from the most prevalent E. coli strains isolated from broiler chickens found to have avian colibacillosis in Guangdog, south of China between 2005 and 2008. In Sharkia governorate, Egypt, E.coli O55, O78 were also detected by (Osman, 1992) .E.coli O126, O55 ,O8, O78,O114, O44 recovered by (Taha, 2002). In regard to other poultry species, our results partially correspond with Hegazy (1992), who isolated E.coli O128, O126 and O114 from 3 flocks of ducks. E.coli O26 and O119 were previously detected in Mansura city, Dakahlia governorate (El-Sayed et al., 2002). 
Our PCR results confirmed that all identified E. coli serotypes were classified to belong to APEC, Patterns and combinations of virulenceassociated genes for 9 APEC strains.Although the specimen origins of APEC strains were diverse, the existence of virulence-associated genes had similar patterns.

On average, detection rate of Irp2, iron, ompT, iss and hly genes showed that they existed in APEC strains with 100\%. However, astA, IutA and tsh genes were less frequently detected in the identified serogroups. These genes were also found in colibacillosis isolates from other countries (Janßen et al., 2001; Delicato et al., 2003; RodriguezSiek et al., 2005), who revealed that multiple potential virulence genes may participate in the pathogenesis of colibacillosis. For instance, other studies showed that the tsh was detected in $19 \%, 49.7 \%, 84 \%$, and $85.3 \%$ of the E. coli strains, respectively (Dozois et al., 2000; Janßen et al., 2001; de Brito et al., 2003; Zhao et al., 2005), whereas in about $75 \%$ of the strains in this study and in $39.5 \%$ of the colibacillosis strains (Delicato et al., 2003). Similarly, the iss gene was detected in $83 \%, 86 \%$, and $38.5 \%$ of the colibacillosis strains (de Brito et al., 2003; Delicato et al., 2003; Zhao et al., 2005), whereas it was found in $100 \%$ of the isolates in this study.

The difference in such associations may be related to virulenceassociated genes, geographical origin, and antimicrobial use of the strains under investigation. Thus different APEC strains can exploit several alternative paths to adhere, colonize, and invade their hosts .In regard to the isolated serogroups, we observed that E.coli O2, O78 and 
O86 had 100\% of all tested virulence related genes. This finding goes in line with Vidotto et al., (1990) who mentioned that avian pathogenic E.coli most commonly belongs to $\mathrm{O} 1, \mathrm{O} 2$, or $\mathrm{O} 78$ and typically possesses virulence factors such as lipopolysaccharide, temperaturesensitive hemagglutination (Tsh), and increased serum survival factor (ISS).

Antimicrobial therapy is one of the important measures for reducing significant economic losses to the poultry industry caused by colibacillosis.

In our study, sensitivity test showed that O26 and O127, which were the majors serotypes isolated from turkey, ibis and quail were weakly sensitive to ciprofloxacin.this result corresponds with MuellerDoblies et al., (2013) who recorded ciprofloxacin resistant E. COLI isolates in turkey hatcheries in the United Kingdom.

This finding goes in line with Vidotto et al., (1990) who mentioned that avian pathogenic E.coli most commonly belongs to $\mathrm{O} 1, \mathrm{O} 2$,or $\mathrm{O} 78$ and typically possesses virulence factors such as lipopolysaccharide, temperature- sensitive hemagglutination (tsh), and increased serum survival factor (ISS).

In conclusion, experimental infection of Ross chicken with different E.coli serotypes led to significant reduction in the mean feed intake and body weight and increase in the feed conversion ratio. The worst effects were recorded in case of E.coli and O87. These results were considered reasonable due to these two serotypes harboring $100 \%$ of the virulent factors tested in our study. 
Incidence Of Pathogenic Eschesichia Coli In Some Poultry ...
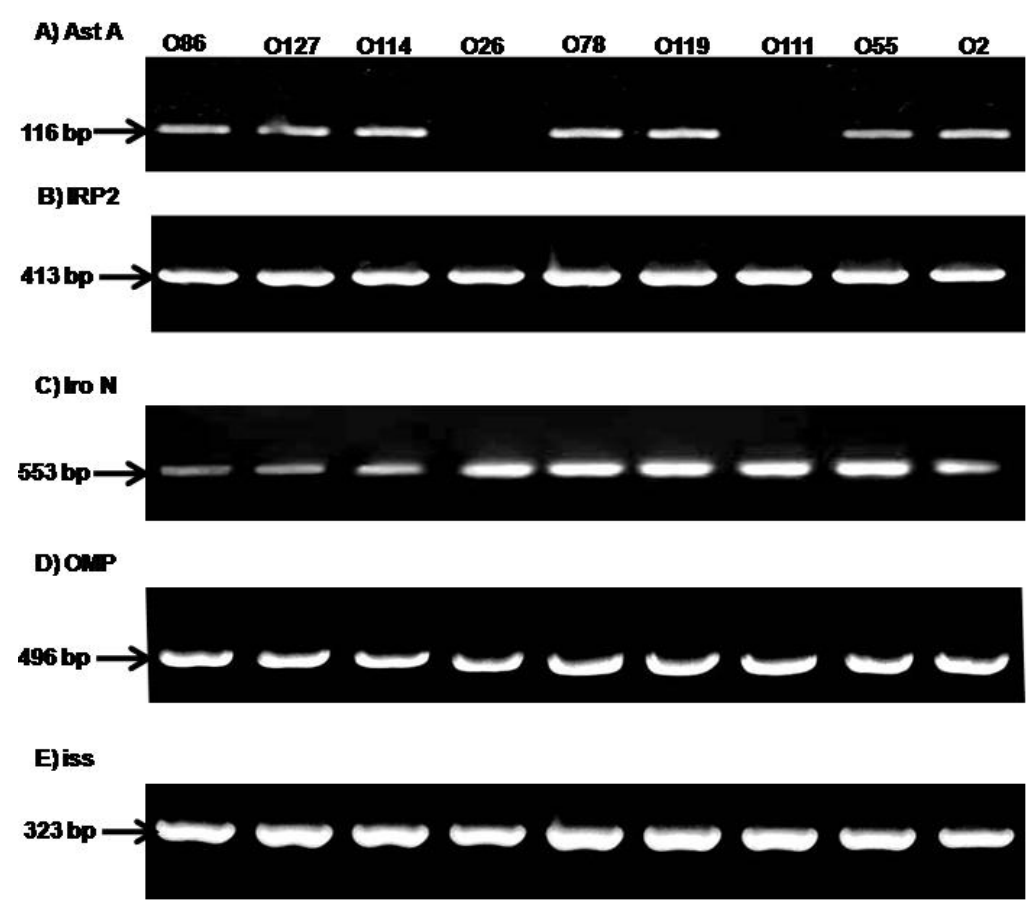

Finly

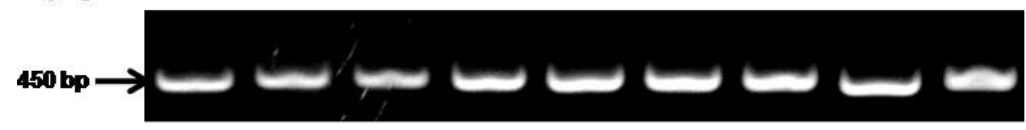

G) iut

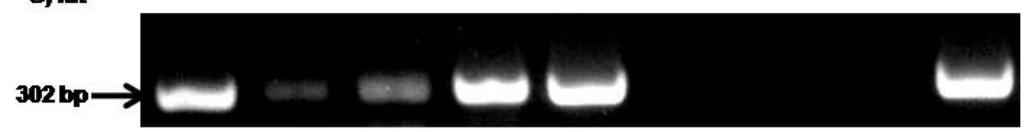

H) tsH

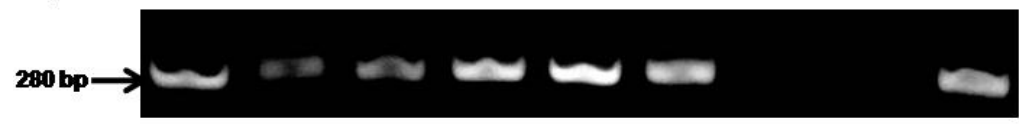

Fig. (1): Amplicon patterns of virulence-associated genes by PCR.

DNA bands for: A) astA; B) irp2 ;C) iroN; D) ompT; E) iss; F) hlyF; G) IutA; H) tsh in the different serotypes of $\mathrm{E}$. coli isolated from different poultry species. The PCR conditions were declared in the material and methods section. The marker size (bp) was declared with arrow beside the referred band 


\section{REFERENCES}

- Aerts MML, Hogenboom AC and Brinkman (1995). Analytical strategies for the screening of veterinary drugs and their residues in edible products. J. Chromatogs. 667:1-20.

- Boom, R., Sol, C. J. A., Salimans, M. M. M., Jansen, C. L., Wertheim-Van Dillen, P. M. E. and Van Der Noordaa. J. 1990. Rapid and simple method for purification of nucleic acids. Journal of Clinical Microbiology, 28 (3): 495-503.

- Brasil (2006). Setor de Estatistica, Servico de Inspecao Federal, Delegacia Federal de Agricultura e Reforma Agraria, Ministerio da Agricultura, do Abastecimento e da Reforma Agraria, Brasilia, DF.

- Cloud SS., Rosenberger JK., Fries PA., Wilson RA and Odor EM. (1985). In vitro and in vivo characterization of avian Escherichia coli.I. Serotypes, metabolic activity, and antibiotic sensitivity. Avian Dis. 29: (4) 1084-93.

- de Brito B, Gaziri LC, and Vidotto MC. (2003). Virulence factors and clonal relationships among Escherichia coli strains isolated from broiler chickens with cellulitis. Infect Immun. 71:4175-4177.

- Delicato ER, de Brito BG, Gaziri LC, and Vidotto MC. (2003). Virulenceassociated genes in Escherichia coli isolates from poultry with colibacillosis. Vet Microbiol. 94:97-103.

- Dozois CM, Dho-Moulin M, Brée A, Fairbrother JM, Desautels C, Curtiss R.2000. 3rd: Relationship between the tsh autotransporter and pathogenicity of avian Escherichia coli and localization and analysis of tsh genetic region. Infect Immun. 68: 4145-4154 
- El-Sayed M., El-Gaml, A. M., El-Nagar M. and Moustafa A. H. (2002). Studies on antibacterial activity of Nigella sativa seed oil on some pathogenic organisms from chicken Meat. Zag. Vet. J. 29 (2): $32-42$.

- Ewers C, Janssen T, Kiessling S, Philipp HC, Wieler LH (2005). Rapid detection of virulence-associated genes in avian pathogenic Escherichia coli by multiplex polymerase chain reaction. Avian Dis 49: 269-273.

- Gomis M. S., Riddell C., Potter A. A. and Allan J. B. (2001). Phenotypic and genotypic characterization of virulence factors of Escherichia coli isolated from broiler chickens with simultaneous occurrence of cellulitis and other colibacillosis lesions. The Canadian Journal of Veterinary Research 65: 1-6.

- Gyles C. (2008). Antimicrobial resistance in selected bacteria from poultry. Anim Health Res Rev. 9:149-158.

- Hegazy A. H. (1992). Epidemiology of E.coli in ducks. Egyptian Journal of Applied Sciences 7 (4): 548-556.

- Hui A. K., Das R. and Mandal M. (2002). Studies on pathogenicity of E.coli in one week old kahaki Campell ducklings. Journal of Interacademica 6(2): 206-209.

- Janßen T, Schwarz C, Preikschat P, Voss M, Philipp H, and Wieler LH. 2001. Virulence-associated genes in avian pathogenic Escherichia coli (APEC) isolated from internal organs of poultry having died from colibacillosis. Int J Med Microbiol. 291: 371-378. 
- Johnson TJ, Siek KE, Johnson SJ, Nolan LK (2006). DNA sequence of a ColV plasmid and prevalence of selected plasmid-encoded virulence genes among avian Escherichia coli strains. J Bacteriol 188: 745-758.

- Jordan F. T., Williams N. J., Wattret A. and Jones T. (2005). Observations on salpingitis, peritonitis and salpingoperitonitis in a layer breeder flock. Veterinary Record. 157(19):573-577.

- Kok, T.; Worswich, D. and Gowans, E. (1996). Some serological techniques for microbial and viral infections. In Practical Medical Microbiology (Collee, J.; Fraser, A.; Marmion, B. and Simmons, A., eds.), 14th ed., Edinburgh, Churchill livingstone, UK.

- Mueller-Doblies D., Clouting C, Davies RH. 2013. Investigations of the distribution and persistence of Salmonella and Ciprofloxacinresistant Escherichia coli in Turkey hatcheries in the UK. Zoonoses Public Health. In Press.

- Nain S, and Smits JE. 2011. Validation of a disease model in Japanese quail (Coturnix coturnix japonica) with the use of Escherichia coli serogroups O2 isolated from a turkey. Can J Vet Res. 75(3): 171-5.

- Oh J. Y., Kang M. S., Kim J. M., An B. K., Song E. A., Kim J. Y., Shin E. G., Kim M. J., Kwon J.H. and Kwon Y.K.(2011). Characterization of Escherichia coli isolates from laying hens with colibacillosis on 2 commercial egg-producing farms in Korea. Poultry Science. 90(9): 1948-54.

- Osman M. M. M. (1992). Studies on bacterial causes of early poultry mortality in Sharkia Govrnorate. Master Thesis, Department of Microbiology (Bacteriology), Fac. Of Vet. Med., Zagzig University, Egypt. 
- Provence DL, Curtiss $R$ (1994). Isolation and characterization of a gene involved in hemagglutination by an avian pathogenic Escherichia coli strain. Infect Immun 62: 1369-1380.

- Qadri F., Haque A., Faruque S. M., Bettelheim K. A., RobinsBrowne R. and Albert M. J. (1994). Hemagglutinating properties of enteroaggregative Escherichia coli. Journal of Clinical Microbiology 32(2):510-4.

- Rodriguez-Siek KE, Giddings CW, Doetkott C, Johnson TJ, and Nolan LK. 2005. Characterizing the APEC pathotype. Vet Res. 36:241-256.

- Taha N. A. A. (2002). Zoonotic importance of enteropathogenic E.coli APEC. Ph. D. Thesis, Zooonosis, Fac. Of Vet. Med. Zagazig University, Egypt.

- Vidotto M. C., Muller E. E., de Freitas J. C., Alfieri A.A., Guimaraes I.G. and Santos D.S. (1990). Virulence factors of avian Escherichia coli. Avian Diseases 34(3):531-538.

- Xi Y, Wood C, Lu B, Zhang Y. (2007). Prevalence of a septicemia disease in the crested ibis (Nipponia nippon) in China. Avian diseases. 51: (2) 614-617.

- Yousseff, F. M., Ahmed, M. A. and Mansour, D. H. (2008). Clinical, Pathological and Bacteriological Investigations on Air Sacculitis in Chickens in IsmailiaProvince (Egypt). Journal of Agricultural and Veterinary Sciences, 1: (2)71-79.

- Zhao S, Maurer JJ, Hubert S, De Villena JF, McDermott PF, Meng J, Ayers S, English L, and White DG. 2005. Antimicrobial susceptibility and molecular characterization of avian pathogenic Escherichia coli isolates. Vet Micro. 


\section{نسبة حدوث مكروب القولوني الممرض في بعض سلالات الدواجن في مصر وتأثير ها علي أداء الدجاج}

APEC) بنسب مرتفعة (57096\% من الدجاج والبط والحمام والرومي وابو قردان والسمان) تم عزل الميكروب القولوني المـرض و 25048\%، 501\%، 4046\%، 3082\%، 3018\%) علي التوالي و كانت نسبة العزل من القلب والرئتين والكبد مرتفعة وتم تصنيفها سيرولوجيا فكانت كالأتي:

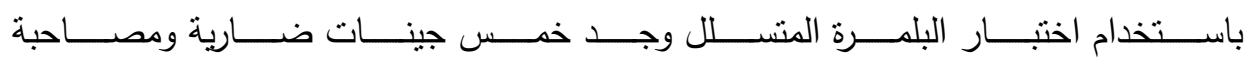
لـ O26, O127, O55, O119, O111, O78, O86, O2, O114 . بالعدوى الصناعية بهذه المعزولات في الدجاج والسمان كان irp2 , iron, ompt, iss and hlyf ـ وهي نسبة وفيات عالية 50-60\% علي التوالي مع انخفاض شديد في متوسط الأوزان من 20\%-30\% أعطوا O2,O78 كما تم دراسة حساسية هذه للمضادات الحيوية المختلفة. 